\title{
THE CENTRAL ROLE OF TAXONOMY IN THE STUDY OF NEOTROPICAL BIODIVERSITY ${ }^{1}$ \\ Laura P. Lagomarsino ${ }^{2 *}$ and Laura A. Frost ${ }^{2}$
}

\begin{abstract}
The Neotropics are the most species-rich area of the planet. Understanding the origin and maintenance of this diversity is an important goal of ecology and evolutionary biology. Success in this endeavor relies heavily on the past work of taxonomists who have collected specimens and produced the floras and monographs that constitute the foundation for the study of plant diversity. To illustrate this, we visualize collecting efforts through time and identify the importance of past taxonomic and collection efforts in generating the bulk of specimen data that broad-scale analyses rely on today. To demonstrate the importance of taxonomy for the study of Neotropical biodiversity, we showcase selected plant groups in which in-depth taxonomic understanding has facilitated exciting evolutionary and ecological research and highlight the teams of scientists who have built on the legacy of Alwyn Gentry, one of the most prolific taxonomists of the late 20th century. We also discuss challenges faced by taxonomists, including perceived subjectivity, difficulty in measuring impact, and the need to become more interdisciplinary. We end with potential solutions going forward, including integration of taxonomists in interdisciplinary research, advocacy for continued collection efforts, increased funding for alpha taxonomic research that is performed with increasingly replicable methodology, and explicit decolonization efforts to increase inclusivity and equity in the field of taxonomy. Acknowledging the central role of taxonomy and taxonomists is essential to accurately and completely describe Neotropical biodiversity patterns in an age of unprecedented extinction risk and conservation need.

Key words: Biodiversity, Central America, decolonialization, floristics, herbarium, monography, museum-based research, South America, taxonomic impediment.
\end{abstract}

For centuries, scientists have tried to understand the distribution of life on earth and why some geographic regions house much higher species diversity than others. The latitudinal species diversity gradient, with species richness being highest surrounding the equator and decreasing toward the poles (Hawkins, 2001), is a classic area of inquiry. Likewise, the high species richness in the Neotropics compared to other tropical regions of the globe has inspired innumerable research programs (see Antonelli \& Sanmartín, 2011). Understanding the origin and maintenance of this exceptional biodiversity is a fundamental aim of ecology and evolutionary biology today (Antonelli et al., 2017).

It is not surprising that these questions have attracted researchers across subfields, many of which were highlighted in the 66th Annual Fall Symposium of the Missouri Botanical Garden. Evolutionary studies, including phylogeographic analyses of widespread taxa that demonstrate the importance of dispersal barriers in structuring genetic diversity (Dick \& Heuertz, 2008; Nazareno et al., 2017) and clade-focused phylogenetic studies that make a case for both biotic and abiotic factors in driving diversification across the Neotropics (Lagomarsino et al., 2016), shed light on the origin of this biodiversity. On more recent time scales, community ecology provides insights into the coexistence of species in diverse communities (Eck et al., 2019) and the role of environmental gradients in structuring plant phenotypic diversity (Umaña \& Swenson, 2019), both of which are likely tied to plant secondary chemistry (Sedio, 2017) and regional attributes (Ricklefs \& He, 2016). These studies demonstrate how extant biodiversity is maintained. Paleobiology further links major changes in climate and landscape, such as mountain uplift and changes in drainage systems, to shifts in biodiversity over deep geological timescales (Claramunt

1 L. P. L. would like to thank Mónica Carlsen, Sebastián Tello, and James Miller, the organizers of the 66th Annual Fall Symposium of the Missouri Botanical Garden, for their hard work in assembling a diverse lineup of speakers, and for including her among them. L. P. L.'s time at MO between 2015 and 2017, funded by a National Science Foundation Postdoctoral Research Fellowship in Biology (grant no. 1523880), shaped many of the ideas presented here, especially conversations with: Tom Croat, Roy Gereau, Michael Grayum, Iván Jimenéz, Ron Leisner, Jim Miller, Rosa Ortiz-Gentry, John Pruski, Jim Solomon, Peter Stevens, Charlotte Taylor, Carmen Ulloa-Ulloa, Henk van der Werf, and Jim Zarucchi†. Even while these individuals may have been influential to our thinking, they certainly may not agree with everything we have written. Lúcia Lohmann, Doug Daly, Paul Fine, and Sandra Knapp provided invaluable comments that resulted in an appreciably better, more balanced manuscript, and, as always, conversations and comments from Daniel Santamaría-Aguilar resulted in further improvements. L. P. L. and L. A. F. are funded by a grant from the Louisiana Board of Regents Research Competitiveness Subprogram. We dedicate this manuscript to all Neotropical plant taxonomists, past and present, who have devoted their lives to cataloging the most species-rich area of the world, thereby providing the basis for our current understanding about the biodiversity of this incredibly diverse region.

2 Shirley C. Tucker Herbarium, Department of Biological Sciences, Louisiana State University, Baton Rouge, Louisiana, U.S.A.

* Author for correspondence: llagomarsinol@lsu.edu 
\& Cracraft, 2015), and recent millennia (Pupim et al., 2019; Åkesson et al., 2020).

The study of Neotropical biodiversity patterns is becoming increasingly interdisciplinary, merging techniques from various subdisciplines (Ribas et al., 2012; Bacon et al., 2015; Salazar et al., 2018; Hoorn et al., 2019). The robust community that studies Neotropical biodiversity benefits immensely from the past work of taxonomists (Mori, 1992). Indeed, these professionals are often the unsung heroes in broad studies of biodiversity. The floras and monographs that they author and the collections they make in the field represent the primary resources for biodiversity documentation. Likewise, their hypotheses about species limits are tested explicitly by molecular systematists and represent the basic working units used by ecologists. Furthermore, their deep understanding of specific taxa and/or regional biodiversity has inspired many studies.

Even though taxonomists provide the foundation work to biodiversity science, their contributions are often under-recognized. For example, even though species identification is crucial to reproducibility (Por, 2007) and determination can be incredibly time-consuming (Mori, 1992), taxonomists' identifications are rarely acknowledged in publications. Likewise, the checklists, floras, and monographs that inspire so many ecological projects and from which data are mined for large-scale studies often go uncited, devaluing the massive amount of labor necessary to compile those lists. Further, the botanists who collect the bulk of contemporary herbarium specimens see no benefit in their profile or reach relative to those that do not voucher their research.

Here, we argue that without foundational knowledge of alpha taxonomy, the research featured in the 66th symposium of the Missouri Botanical Garden would not have been possible. It is thus appropriate that many speakers honored Alwyn Gentry's scientific legacy. Gentry's hypotheses remain a cornerstone in the study of Neotropical biodiversity; perhaps less widely known, Gentry was also one of the most prolific taxonomists of the late 20th century (Miller et al., 1996).

\section{The Taxonomic Impediment and the Importance of EXPERT KNOWLEDGE}

One of the most important goals of biology is to produce a complete inventory of all Earth's biodiversity, including a list of all of species found on Earth and a comprehensive Tree of Life (Cardoso et al., 2011; Hinchliff et al., 2015). Many exciting developments in the last half century, including molecular phylogenetics, phylogenomics, and large-scale natural history collection digitization efforts, have pushed the boundaries of systematics in exciting new ways (Sauquet \& Graham, 2016). This has resulted in a much more refined understanding of relationships among organisms, facilitating broad comparative analyses that have shed light on the generalities of the evolutionary process (Hinchliff et al., 2015; Diaz et al., 2019; One Thousand Plant Transcriptomes Initiative, 2019). However, basic monographic work, the foundation of all biodiversity studies (Heywood, 2001), has not kept pace, with estimates suggesting that this branch of study has been either in decline or in a period of relative stagnation in recent decades (Heywood, 2001; Tancoigne \& Dubois, 2013; Bebber et al., 2014; Miralles et al., 2020). This is despite the complementary nature of these subdisciplines of systematics. Indeed, while phylogeneticists test hypotheses formulated by taxonomists and published in monographs, taxonomists re-circumscribe taxa to reflect the evolutionary relationships published by phylogeneticists.

The ability to accurately name species and to describe new diversity as it is discovered is key to understanding broad biodiversity patterns. However, the subset of researchers who are trained to do this is small, and is actually shrinking as many experts head into retirement without guaranteed lines to replace them (Gaston \& May 1992; Buyck, 1999). This illustrates the taxonomic impediment (Cardoso et al., 2017), which refers to the disconnect between the diminishing pool of researchers who generate floristic inventories and make taxonomic decisions, and those who use them. Lack of basic taxonomic understanding has measurable consequences. First, it means that only a small subset of the biology community has the skills to identify organisms, especially in species-rich tropical regions, and a resultingly small subset can describe new diversity as it is encountered (Wheeler, 2020). Second, it implies that changing taxonomic concepts are curated by a relatively small number of employed taxonomists, each with a necessarily narrow realm of specialty, leading to massive numbers of misidentified specimens in herbaria (Goodwin et al., 2015). This is perhaps exacerbated by the increased reliance on specimens from plot inventories for understanding ecology of Neotropical ecosystems. While these studies generate important data that are directly connected to herbarium vouchers, up to $50 \%$ of these specimens are thought to be erroneously identified (Baker et al., 2017), perhaps in part because they rely initially on identifications made by parataxonomists (Basset et al., 2004).

There are crucial consequences of the taxonomic impediment in the study of global diversity patterns. While macro-ecological and evolutionary studies rely on exhaustive lists of species in different geographic regions and biomes, incorrect identifications abound in large databases (e.g., iDigBio, GBIF). Misidentifications in these datasets can lead to significant errors in largescale studies, including incorrect richness estimates and 
species identity (Cardoso et al., 2017), overestimation of species richness in poorly explored areas (Maldonado et al., 2015), and inaccurate species distribution models (Oleas et al., 2019). Indeed, Cardoso et al. (2017) documented up to $40 \%$ error rate in non-taxonomically verified checklists aggregated from publicly available databases. Inaccurate datasets are a clear threat to the accurate understanding of broad patterns of biodiversity. Even though they entail significant investments of time and personnel, every attempt to use large databases in biodiversity studies should involve detailed taxonomic verification and various data-cleaning procedures.

\section{Herbaria as a Source of Diverse Data Types to Study the Past, Present, and Future of Biodiversity}

One of the most exciting changes in the study of biodiversity in recent years is a resurgence in the use of museums and specimen-derived data in a broad range of biological inquiry. This has been bolstered by specific funding programs by the U.S. National Science Foundation (NSF), including the Postdoctoral Research Fellowships in Biology "Interdisciplinary Research Using Collections," "Advancing Digitization of Biodiversity Data," and "Planetary Biodiversity Inventories" programs. Outside of the United States, the digitization of historic herbaria in Europe, including the Natural History Museum (BM), Royal Botanic Gardens, Kew (K), the Muséum national d'Histoire naturelle $(\mathrm{P})$, and the Naturhistorisches Museum Wien (W), is of particular importance to Neotropical botany; these herbaria hold many type specimens and collections by notable early explorers of the Neotropics. In addition to stimulating research, this increased investment in collections-based research has spurred simultaneous growth and use of large databases of collections data and images, including iDigBio (<https://www.idigbio.org/ $>$ ) and the Global Biodiversity Information Facility (GBIF; < https://www.gbif.org/ $>$ ). The Global Plants database (<https://plants.jstor.org/>) has made type images from around the globe available online; however, while its original intent was to empower researchers around the world (especially the Global South) with access to these important specimens, institutional fees now make this a challenge.

The recent emphasis on collections-based research has resulted in a renaissance in biology (Funk, 2018). We have gained more in-depth understanding of phenology (Hart et al., 2014; Park et al., 2018), morphological evolution (McAllister et al., 2018), the impacts of climate change on plant-animal interactions (Meineke \& Davies, 2018), and shifting species ranges (Vellend et al., 2013). These advances would not have been possible without the depth of data through space and time granted by collections. Improved molecular techniques have also allowed us to generate genome-scale
DNA sequence data (Hart et al., 2016), revolutionizing the field of molecular systematics (Chomicki \& Renner, 2015; Iles et al., 2017; Dodsworth et al., 2019), a traditional realm of museum specimens. Further, the use of degraded DNA from specimens has contributed to other biology subfields such as population genetics (Martin et al., 2016), local adaptation (Exposito-Alonso et al., 2018), and microbiome ecology and evolution (Daru et al., 2018a).

Because of the increased interest in natural history collections and their associated data, a more diverse array of scientists has been introduced to the inner workings of museums than ever before. We hope that this has helped museums move away from a longstanding stereotype that taxonomists are misanthropes who prefer to work in isolation. This is especially important as it is likely that an even broader community of end users of collections data will exist in the future (Schindel \& Cook, 2018; Lendemer et al., 2020). It is crucial to remember, though, that these creative, often broad-scale studies that are being undertaken within collections are only possible thanks to the massive collecting efforts of the past. In particular, the resurgence in floristic research in the 1970s through the early 2000s led to major growth in Northern Hemisphere herbaria, as discussed below. These specimens, and the taxonomists whose hard-earned specialist knowledge aided the application of valid names, power most of the research conducted on the origin and maintenance of Neotropical biodiversity today. While it is heartening to see increased interest in natural history collections, their future utility hinges on the continued investment in taxonomy, which represents the foundation for highquality biodiversity research (Wheeler, 2020).

\section{Contributions of Historical Collections to Our Modern Understanding of Neotropical Biodiversity}

Understanding the origin and maintenance of Neotropical biodiversity is difficult not only because of the complexity of the ecological and evolutionary processes that generated these patterns, but also because of the enormous challenge of simply documenting and describing diversity. Biodiversity documentation requires funding and the long-term dedication of teams of taxonomists, knowledgeable field guides, artists, and photographers. These efforts are not frequently undertaken; however, major events in the history of Neotropical botanical exploration, including significant expeditions, the development of institutions dedicated to the study and preservation of biodiversity, floristic projects, and botanical surveys, have shaped much of what we know about the Neotropical flora today.

Herbarium specimens are the medium through which taxonomic and systematic work is accomplished, and, 
with increased frequency, often form the basis of ecological and evolutionary studies. Much of the Neotropics is under-collected relative to temperate regions, especially given its high species diversity. We examined the degree to which each Mesoamerican and South American country has been botanically explored and documented using the metric of vascular plant collections per land area $\left(\mathrm{km}^{2}\right.$; Fig. 1). For comparison, we also included this metric for the United States and Spain. Costa Rica, by far, has the best-represented flora in digitized herbaria among all Latin American countries. This is undoubtedly due to a long history of botanical expeditions, institutional support, and flora projects in Costa Rica.

To better understand how major events, including floristic projects initiated by Missouri Botanical Garden, correlate with increases in herbarium collections, and, thus, our knowledge of the plant diversity in those areas, we assembled timelines of collection for selected countries in Central America (Nicaragua, Costa Rica, and Panama; Fig. 2) and South America (Venezuela, Colombia, and Ecuador; Fig. 3). Estimates of the number of collections of vascular plants per year were taken from the number of preserved specimen occurrences reported for Tracheophytes in GBIF. These timelines were compared to major events in the history of botanical exploration for each country, which were confirmed from the literature (Nicaragua: Stevens et al., 2001; Montiel \& Stevens, 2019; Costa Rica: Polakowsky, 1879; Durand \& Pittier, 1891; Durand et al., 1893; Tonduz, 1895; Pittier, 1908; Dodge, 1933; Standley, 1937; Jiménez-Luthmer, 1969; Gómez \& Savage, 1983; McCook, 1999; León, 2002; Hammel et al., 2004; Panama: Dwyer, 1964; Woodson \& Schery, 1980; Moreno, 2004; Venezuela: Huber \& Wurdack, 1984; Berry et al., 1995; Colombia: Pinto \& Ruiz, 1984; Forero, 1988; Callejas \& Idárraga, 2013; Villamil-Montero \& Ming, 2016; Diazgranados et al., 2019; Ecuador: Diels, 1937; Acosta-Solis, 1969; Wiggins et al., 1971; Renner, 1993; Jørgensen \& León-Yánez, 1999; and the Missouri Botanical Garden website: < http://www.mobot.org/MOBOT/ Research/>).

In each case, major expeditions, the establishment of institutions (e.g., national herbaria, Instituto Nacional de Biodiversidad [INBio] in Costa Rica, the Smithsonian Tropical Research Institute [STRI] in Panama) and academic programs (e.g., the Organization of Tropical Studies in Costa Rica), floristic projects, and ecological surveys all had noticeable impacts on the number of collections made (Figs. 2, 3). These projects and institutions have bolstered our knowledge and understanding of species numbers, distribution, composition, and community assembly of the Neotropical flora as a whole.

This understanding necessarily reflects known cultural and logistic biases in biodiversity data (Hijmans et al., 2000; Funk \& Richardson, 2002; Meyer et al., 2016; Troudet et al., 2017; Daru et al., 2018b). Most relevant to the data presented above are temporal and collector bias. For example, the time of year in which collectors tend to go to the field creates temporal bias in natural history records, which can extend into years when collecting activity peaks or plummets (Funk \& Morin, 2000; Norris et al., 2001). These bumper years, as demonstrated by our timelines (Figs. 2, 3), often correlate with specific projects or expeditions. This may introduce collector bias, and, in fact, the majority of collections in many developing tropical countries result from few prolific collectors, resulting in an overrepresentation of their preferences, including proclivities for specific taxa, habitat types, or regions (Hijmans et al., 2000; Daru et al., 2018b). Cultural and logistic bias associated with the collection of certain taxa or clades over others leads to taxonomic and phylogenetic bias (Hortal et al., 2007). For example, arachnids, insects, and other invertebrates are underrepresented in collections, while birds and angiosperms are overrepresented, a trend that has increased over time (Troudet et al., 2017). Geographic bias, also known as "roadside bias," refers to the higher density of collections made in areas accessible by transportation, like roadsides and riverbanks, and those surrounding major urban hubs and institutions, including herbaria and museums (Hijmans et al., 2000; Funk \& Richardson, 2002; Loiselle et al., 2007). Additionally, each source of bias is accompanied by a level of taxonomic, geographic, and temporal uncertainty in the associated digitally accessible information. Biases and uncertainty limit the utility of broader applications (e.g., range maps and niche modeling) for the understanding of current biodiversity patterns, complicating future biodiversity projections and the accurate documentation of species composition and distribution patterns over time (Meyer et al., 2016; Troudet et al., 2017).

Beyond an improved understanding of which and how many species occur in the Neotropics, collectors have also generated hypotheses about the processes underlying biodiversity patterns. For example, during his Andean expedition, Alexander von Humboldt noticed that temperatures decreased as elevation increased, and, concomitantly, plant species changed (von Humboldt \& Bonpland, 1807). From these observations, the hypothesis of altitudinal zonation was developed and remains a topic of investigation to this day (Snowden, 1933; Johns, 1985; Ohsawa et al., 1985; Druitt et al., 1990; Frahm \& Gradstein, 1991; Uhlig \& Uhlig, 1991; Pendry \& Proctor, 1996; Kessler, 2000; Sklenár, 2006). Similarly, Alwyn Gentry is perhaps best known for his long-standing hypotheses regarding the origin and maintenance of Neotropical floristic diversity, especially how it relates to biogeography and landscape change through time (Gentry, 1982a, 1982b, 1988, 1992). His taxonomic background (further discussed below) and 


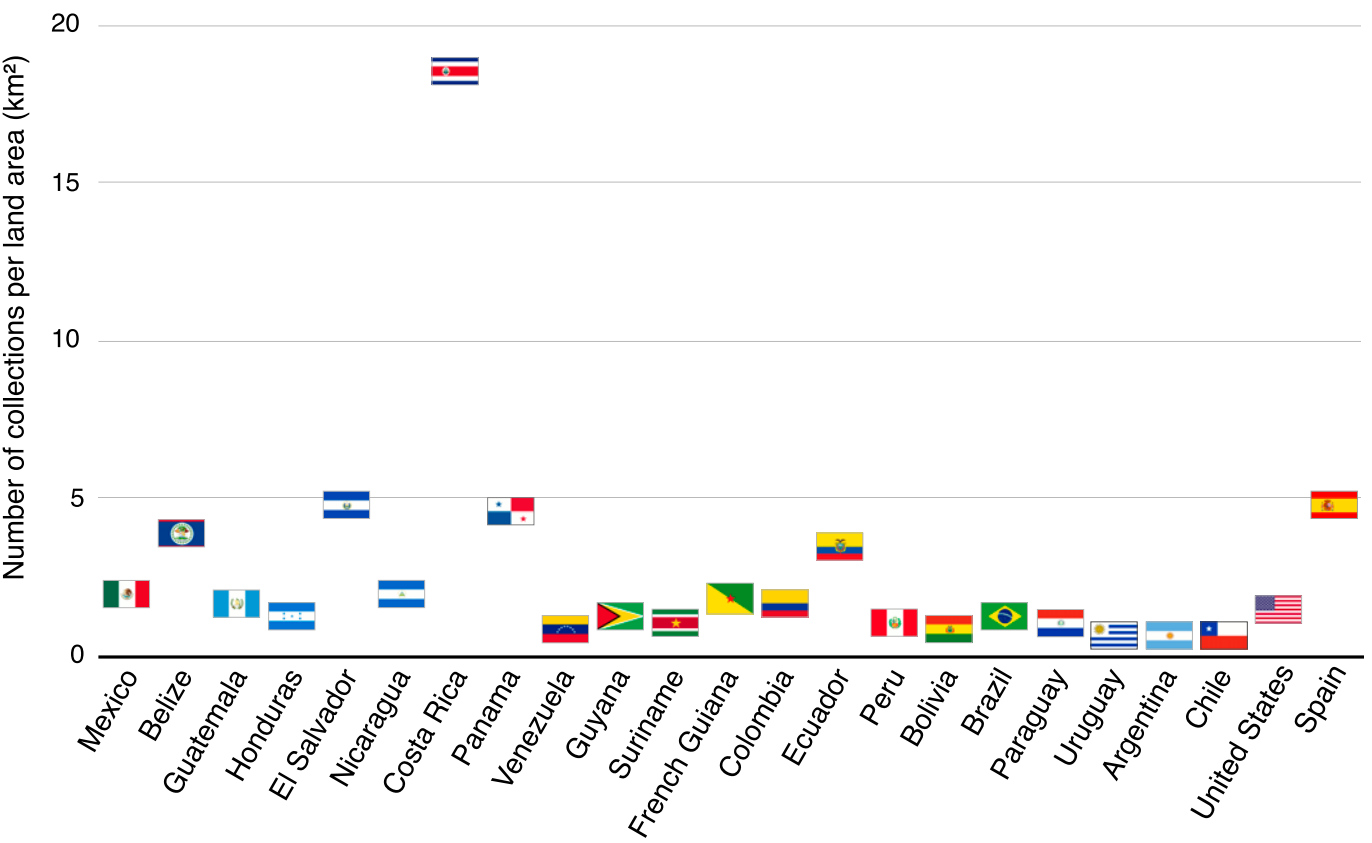

Figure 1. Number of vascular plant collections per land area $\left(\mathrm{km}^{2}\right)$ for Mesoamerican and South American countries. Number of collections for each country is based on the number of preserved specimen occurrences of Tracheophyta reported in GBIF $(<$ https://www.gbif.org/ $>$ ).

abundant time spent making observations in the field inspired his hypothesis that "Amazonian-centered" clades of lowland canopy trees and lianas have evolutionary histories that contrast with "Andean-centered" clades of mid- to highelevation epiphytes, understory shrubs, or large monocots (Gentry, 1982a). This remains a major biogeographic hypothesis tested by systematists (Fleming et al., 1987; Clark, 1990; Taylor, 1991; Cuesta-Camacho et al., 2006; Pirie et al., 2006; Quijano-Abril et al., 2006; Pennington \& Dick, 2010; Pinto et al., 2012; Lagomarsino et al., 2017), and has become so ingrained in Neotropical botany that researchers often present their study systems as "Amazonian-centered" (e.g., Macrolobium Schreb. section Macrolobium [(Murphy et al., 2018)], Swartzia Schreb. [Pinto et al., 2012]), or "Andean-centered" (e.g., Bambusoideae [Clark, 2001], Centropogon C. Presl [Lagomarsino et al., 2016], Heliconia L. [Andersson, 1989]). Humboldt's and Gentry's contributions exemplify how the powerful combination of taxonomic expertise and extensive field observations can drive fields of study for decades or centuries.

In the Spirit of Al Gentry: Examples of InNovative Neotropical Biodiversity Research Powered by Taxonomic KNowledge

Gentry's hypotheses have stood the test of time and laid the foundation for research into Neotropical floristics and biogeography that continues through today.
Gentry spent substantial time collecting plant specimens throughout the Neotropics, becoming acquainted with the taxonomic and morphological diversity of the flora. He was a consummate taxonomist, especially of Bignoniaceae, a group he worked on for his entire career and for which he contributed treatments for numerous floras (Miller et al., 1996). Gentry's contributions to the study of Neotropical botany resulted directly from his deep taxonomic understanding of this focal group and its place within the broader context of Neotropical forests. Many of his insights came from establishing 226 transects (now known as "Gentry plots") in geographically distinct regions (Phillips \& Miller, 2002), allowing him to consolidate his taxonomic and ecological data into a unified theory of Neotropical biogeography. Begun initially as an avenue to understand the ecology of Bignoniaceae (Miller et al., 1996), these plots transformed into a key resource for the understanding of the taxonomic composition and overall patterns of plant diversity across tropical forests. Arguably, it is Gentry's training and efforts as a taxonomist that allowed him to become not only one of the best tropical plant identifiers who has ever lived, but also one of the most important scientific thinkers of the 20th century.

Many researchers or groups of researchers have adopted similar approaches to understanding the ecology and evolution of Neotropical plants. These researchers first develop taxonomic knowledge and 




Figure 2. Number of vascular plant collections per year with timelines of selected events for Nicaragua, Costa Rica, and Panama. Number of collections per year for each country were gathered from the number of preserved specimen occurrences of Tracheophyta reported in GBIF (<https://www.gbif.org/ $>$ ) for each year. Events were confirmed from the literature (cited in main text).

resources for a particular group and, subsequently, use that knowledge to test large-scale hypotheses in ecology and evolution. Below, we highlight a few taxonomic groups that complement Gentry's approach to science, though it should be noted that many additional groups would be equally well represented below. The proliferation of model clades (Donoghue \& Edwards, 2019) to study Neotropical biodiversity is likely thanks in large part to the increased development of methods that facilitate analyses of biodiversity data (e.g., phylogenetic comparative methods and species distribution models).

\section{BIGNONIEAE (BIGNONIACEAE)}

Al Gentry's legacy of Bignoniaceae has been carried forward, largely thanks to the contributions of Lúcia Lohmann's group (Universidade de São Paulo, Brazil) in the tribe Bignonieae. Continued descriptions of new species (e.g., Firetti-Leggieri et al., 2015; Frazão \& Lohmann, 2018), range extensions (e.g., Brito et al., 2018), checklists (e.g., Lohmann, 2010; Lohmann \& Ulloa Ulloa, 2006), floristic treatments (e.g., Lohmann et al., 2018; Costa et al., 2019), synopses (e.g., Lohmann \& Taylor, 2014; Fonseca \& Lohmann, 2019), and monographs (e.g., Medeiros \& Lohmann, 2015; Francisco \& Lohmann, 2018) are conducted in parallel with studies on the phylogenetics (e.g., Lohmann, 2006; Kaehler et al., 2019), biogeography (e.g., Lohmann et al., 2013; Thode et al., 2019), and evolution of traits associated with the climbing habit (e.g., Pace et al., 2011, 2015; Sousa-Baena et al., 2014), insect-plant interactions (Nogueira et al., 2012, 2015), and pollination systems (e.g., Alcantara \& Lohmann, 2010, 2011), among others. Across these diverse works on Bignoniaceae, an in-depth, organismally focused understanding of the ecology and evolution of the largest clade of Neotropical lianas has emerged. As a result, the Bignoniaceae represent as important a clade for understanding the origin and assembly of Neotropical biodiversity and biogeography today as they did when Gentry was active.

\section{SOLANUM L. (SOLANACEAE)}

Despite being one of the largest genera with ca. 1500 species, Solanum is an excellent example of how taxonomic research can inform evolutionary research. Largely thanks to the leadership of Sandra Knapp (Natural History Museum) and Lynn Bohs (University of Utah), there is a large and vibrant community working on various projects related to Solanum and the broader Solanaceae. Taxonomic work in Solanum, including monographs, species descriptions, and floras, is incredibly active (e.g., Barboza, 2013; Stern et al., 2013; Särkinen et al., 2015b; Knapp \& Vorontsova, 2016; Särkinen \& Knapp, 2016; Knapp et al., 2019; Flora do Brasil, 2020). This is paired to frequent phylogenetic 


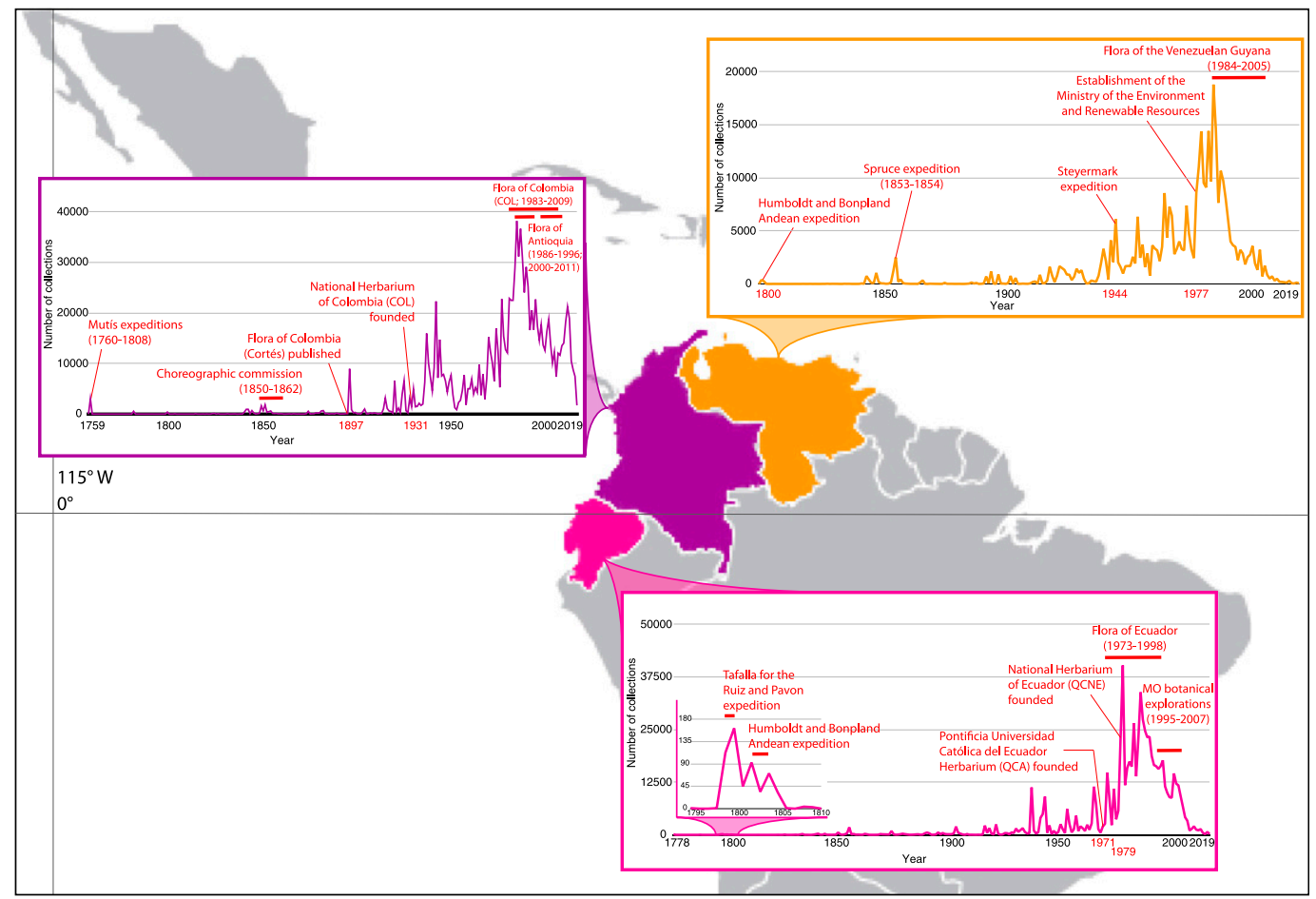

Figure 3. Number of vascular plant collections per year with timelines of selected events for Venezuela, Colombia, and Ecuador. Data collection was the same as in Figure 2.

updates (e.g., Weese \& Bohs, 2007; Särkinen et al., 2013a, 2015a; Spooner et al., 2018; Martine et al., 2019), including macroevolutionary studies (Echeverría-Londoño et al., 2020). Thanks to this relatively complete (though continually updated) taxonomic knowledge, Solanum represents an ideal clade in which to link genomics with various components of biodiversity (Knapp et al., 2004). In fact, Andean tomatoes are becoming a model system to understand evolutionary processes at play in rapid radiations (Baek et al., 2016; Pease et al., 2016; Hamlin \& Moyle, 2019; Nevado et al., 2019). Insights from Solanum have also played a major role in understanding species distributions in the Neotropics (Knapp, 2002; Särkinen et al., 2013b).

\section{PROTIUM BURM F. (BURSERACEAE)}

Protium is used as a model to study ecological and evolutionary dynamics of Amazonian trees (Daly et al., 2012), with an emphasis on edaphic specialization (Fine et al., 2004, 2005, 2013b). The ability to initially pose questions in Protium came from a solid foundation of taxonomy, in recent years especially by Douglas Daly (New York Botanical Garden) (e.g., Daly, 1989, 1992, 2007), complemented by a robust phylogenetic framework established by Paul Fine (University of California, Berkeley) (Fine et al., 2005, 2014). In turn, ecological studies of habitat preferences coupled with new phylogenetic data informed taxonomic revision (Daly \& Fine, 2011, 2018; Damasco et al., 2019; Daly, 2020) and the mechanisms underlying habitat specialization and speciation (Fine et al., 2013a, 2013b; Misiewicz \& Fine, 2014; Misiewicz et al., 2020). Additional research in Protium spans many subdisciplines of ecology and evolution (Zapata \& Fine, 2013; Fortunel et al., 2016; Vleminckx et al., 2018), demonstrating the reach of taxonomically centered research across subdisciplines of biology.

\section{Challenges to Increasing the Reach of Floristics and TAXoNomy}

A major criticism of taxonomy is the field's lack of objectivity (Turrill, 1957), a shortcoming that many systematists acknowledge (Strasser, 2019). Responding to this criticism, statistical methods have been developed over the past few decades to make systematics more data-driven. Molecular systematics is a prime example: using variation in DNA sequences across species, phylogeneticists are able to apply biologically informed models to understand species relationships (e.g., Xi et al., 2012). Species delimitation methods are also catching up to the statistical rigor of phylogenetics, with model-based methods (e.g., Zapata \& Jiménez, 2012; Yang, 2015) 
frequently applied instead of, or in addition to, a taxonomic expert's gestalt. This has resulted in a blooming subfield known as "integrative taxonomy" (SchlickSteiner et al., 2010; Fujita et al., 2012; Prata et al., 2018), which reduces subjectivity and facilitates stability in classification schemes. As a result, descriptive taxonomy is becoming a more rigorous discipline (Sangster \& Luksenberg, 2015). Monography, too, is currently in the midst of a 21 st century revolution (Reginato, 2016; Zapata, 2018).

An additional major impediment to extending floristics and taxonomic research in recent decades has been the difficulty measuring its impact. While tools have been developed to quantify the reach of specimens, including Bionomia (Shorthouse \& Page, 2019; < https:// bionomia.net/ $>$ ), there is a stigma about the limited reach of museums and their curators. Furthermore, floras, monographs, and alpha taxonomic works are not commonly cited, especially outside of the field of systematics (Werner, 2006; Wägele et al., 2011), even when these works are the primary source of data for particular research projects. This results in a reduced academic profile for the researchers who conduct taxonomic research, impacting their career progression. Indeed, hiring and promotion decisions, as well as nominations for awards and fellowships, are made based on metrics including citations (e.g., h-index, i-index) and other non-quantifiable dimensions of "impact" that are not typically associated with herbarium-based researchers, all of which tend to be lower for taxonomists. By devaluing taxonomy, academic culture can stymie the forward progress of the very basic cataloging and description of biodiversity that is so critical for steady scientific progress of all biodiversity-related research. Citing primary taxonomic literature whenever relevant is important to emphasize fairly the importance of this branch of biology, while ensuring that research can be replicated.

Finally, taxonomists need to do a better job integrating with ecologists, evolutionary biologists, policy makers, and the general public. For example, conversation with policy makers, both domestic and international, is crucial to correctly and respectfully implement protocols in the current complex ecosystem of regulations, including the Nagoya Protocol on Access and Benefit Sharing (Rabeler et al., 2019). Further, communication with diverse scientists can begin (or continue) with the development of user-friendly floristic treatments and taxonomic tools, including identification keys and visual floras. Additionally, stability in taxonomy should be a priority, to the extent that it is possible in light of phylogenetic relationships. Taxonomic name changes, especially to plants important in research or horticulture, can cause particular uproar (Lowry et al., 2019), even when they follow taxonomic and nomenclatural best practices (Nesom et al., 2019). In sum, systematists should be considered just as important to answering the major questions of evolutionary biology, ecology, and conservation as experts from other subfields, and should be more commonly integrated into efforts to understand global biodiversity patterns.

\section{Toward an Integrated Future Where Monography and Floristics Are at the Core}

No matter how complex a model or how large an assembled database is, there is no replacement for organismal understanding, the realm of taxonomists. Inclusion of taxonomic experts in large-scale studies of global diversity patterns is a crucial step toward integrating monography and floristics and centering study of the origin and maintenance of Neotropical biology in organismal biology and diversity. This is especially important given the current emphasis on understanding tropical forest diversity and the subsequent implications for conservation and the mitigation of climate change effects (Baker et al., 2017). As we continue to become increasingly interdisciplinary, it is essential that taxonomists are not only seen as a source of specimen identification, but, given their specialist's perspective on organismal biology, also fully integrated into research projects as key members of the team.

Long-term ecological plots that add vouchered specimen distribution information gained in a systematic way provide important insight into how the biodiversity crisis is unfolding in diverse areas, both temperate and tropical. These plots are of huge value as they allow for foundational research into tropical ecology, while contributing to the documentation of biodiversity (Condit, 1995). They also present an opportunity to link taxonomy to large-scale ecological studies. Given that a large proportion of tropical plant species diversity is thought to be undescribed, continued vouchering of these plots is likely to result in substantial species discovery. In fact, taxonomists have already begun to develop floras (Croat, 1978), describe new species and genera (van der Werff \& Nishida, 2010; Kawasaki \& Pérez, 2012), and publish identification guides (Muñoz et al., 2017) across the many long-term forest plot sites. In turn, these taxonomic tools allow researchers to more accurately conduct their research, whether they are ecologists documenting local processes governing community composition or climate change scientists understanding patterns of carbon sequestration.

Despite the important contributions of forest plots to biodiversity research, collections from plots present biases. For example, plots intended for long-term study need to be in areas where researchers can access the plots repeatedly, often in national parks and natural reserves. These protected areas likely provide a different picture of 
species composition than the disturbed areas that represent the most common locations for general botanical collection (e.g., roadsides and pasture edges; Hijmans et al., 2000; Funk \& Richardson, 2002; Loiselle et al., 2007). This results in a mismatch between the habitats for which we have the most in-depth ecological knowledge (i.e., from established plots in forest interiors) and those from which we understand the most about distribution, morphological variation, and taxonomy (i.e., roadsides). Further, sampling is typically restricted to woody plants above a certain diameter at breast height (DBH), and efforts to document herbaceous, lianescent, and epiphytic diversity in long-term plots are much less common (Nieder et al., 2000; Krömer \& Gradstein, 2003; Wolf \& Alejandro, 2003; Flores-Palacios \& García-Franco, 2008; Obermüller et al., 2012; Campos et al., 2015), even though these plants make up a large portion of species diversity, especially in Andean floras (Gentry, 1982a). Additionally, many specimens are sterile and thus, in addition to being time-consuming to identify, are of limited utility to taxonomists (Mori, 1992). We argue that, while maintaining long-term plots is essential to the study of forest dynamics through time and to the basic documentation of biodiversity, broader collection outside of the limited number of plots is also essential.

The continued collection of specimens in a systematic and replicable fashion is especially important as species distributions shift and species extinction risk increases. An increased collection of vouchered plant data requires the input and collaboration of taxonomic efforts, particularly if the resulting data are going to be of maximal utility to a broad user base (Baker et al., 2017). For example, large numbers of accurately identified specimens are key to estimating accurate species distributions (Feeley \& Silman, 2011). In addition to continued collection, it is also important that taxonomists continue to identify specimens in natural history collections. Museum-based research is an important source for species discovery: ca. $50 \%$ of all species of plants that remain to be described are thought to have already been collected and to be sitting in herbaria waiting to be discovered (Bebber et al., 2010). Unfortunately, given high levels of ecosystem destruction and biodiversity loss, floras are increasingly becoming a historical record of what once existed, not what currently exists (Heywood, 2001). With this in mind, there is no more important time to invest actively in the curation and growth of herbaria than the present. As May (1992) noted, there is a time limit to our discipline, and this time may be approaching faster than we realize.

Toward this end, it is crucial that governments and institutions continue to support taxonomic research. This should not be hard to justify, given that funding of taxonomically informed biodiversity studies in recent decades has been very productive. For example, the
NSF Dimensions of Biodiversity grant program "Assembly and evolution of the Amazonian biota and its environment: An integrated approach" resulted not only in important breakthroughs related to understanding the origin and maintenance of Amazonian biodiversity through novel fieldwork and extensive museum-based research (e.g., Weeks et al., 2016; Nazareno et al., 2017; Bemmels et al., 2018; Fine \& Lohmann, 2018; Cracraft et al., 2020), but also in important contributions to a deeper understanding of the poorly known Amazonian geological history (e.g., Cheng et al., 2013; Wang et al., 2017; Pupim et al., 2019). Another important example of ongoing systematic collections efforts in the Neotropics is Kew's Colombia Bio Program (<http:// colplanta.org/ $>$ ), which is actively conducting major expeditions to document plant and fungal flora of this biodiverse country, pairing these with original research and product development, and working directly with Colombian researchers to engender cultural change toward greater awareness and appreciation of biodiversity by the general public and to provide actional recommendations that will help Colombia become more competitive and sustainable in its use of biodiversity (Diazgranados et al., 2019). Importantly, these efforts explicitly include Colombian researchers and partnerships, including support from regional Colombian governments, as well as Kew and U.K. government bodies (see Acknowledging taxonomy's colonial history below).

Continued investment in interdisciplinary work that is centered around taxonomy, including emphasis on under-studied taxa or regions, will result in a better description of biodiversity and a more in-depth understanding of ecological and evolutionary processes. Ultimately, this support is key to mitigating the effects of climate change and developing conservation plans that can effectively reduce extinction risks of key species. Here, it is crucial that support be given to taxonomists so they are able to summarize biodiversity data in comprehensive monographs, develop well-researched floras, and infer the phylogenetic relationships that are so critical for stable classifications and a deeper understanding of the evolutionary and biogeographical history of biotas. Only by supporting curatorial efforts will we improve our understanding of Neotropical plant diversity as a whole.

\section{Acknowledging Taxonomy's Colonial History}

Finally, any call to revitalize taxonomy in the 21 st century would be incomplete without mentioning the importance of decolonizing the field. The history of taxonomy, like allied fields including biogeography (Eichhorn et al., 2020) and field ecology (Baker et al., 2019), is rooted in colonial history. Harkening to the days of Linnaeus, early history of modern taxonomy 
involved European explorers sponsored by imperialist governments bringing species native to colonial territories back to Europe, where they received a Latin name (Heywood, 1983). Even today, though no longer explicitly colonialist, European and North American taxonomists still "discover" and name new tropical species that have had traditional indigenous names for generations (e.g., Whaanga et al., 2013). Further, taxonomic infrastructure, including the number of registered taxonomists and density of biodiversity collections, is underrepresented in megadiverse countries of the Global South, including many in the Neotropics, even though there are still disproportionate levels of biodiversity left to describe in this region (Paknia et al., 2015; Barlow et al., 2018). To increase inclusivity and equity in taxonomy, we must acknowledge this unequal access, confront our painful history, and identify mechanisms in which to center, amplify, and support local perspectives and integrate them into international efforts. A relatively easy first step (though we admit we do not take it here) is to identify and apply alternative terms to refer to the tropical region of the Western Hemisphere; the "New World tropics," "Neotropics," and "American tropics" all reflect a colonizer perspective. Beyond changing colonizer-centered terminology, researchers in the Global North should aim to build capacity in the Latin American countries where they collect specimens and describe new taxa, include authors from those countries in their research and publications, cite research products produced exclusively by Latin American and indigenous scholars, and explicitly include support for Latin American and indigenous researchers in funding applications where possible (Eichhorn et al., 2020).

While taxonomy has historically been performed by white researchers based in Northern Hemisphere institutions, today's ecosystem of Neotropical taxonomy is notably international. This is likely partially due to national and international regulation of biological material in which explicit collaboration with in-country researchers is a condition of approved research plans. However, we also observe many productive, connectionbased collaborative relationships between researchers based in Latin America and the Global North (including ones to which we belong). In order to explore the extent to which modern Neotropical taxonomy is a global enterprise, we explored patterns of authorship in eight journals with a focus on botanical taxonomy (i.e., Anales del Real Jardín Botánico de Madrid, Brittonia, Caldasia, Novon, Phytokeys, Phytotaxa, Systematic Botany, and Taxon). We first downloaded the full citation history for all papers including the Neotropics as a topic from these journals over the past decade (i.e., 2010-2020) from Web of Science (<http://webofscience.com/ $>$ ). We then used the $\mathrm{R}$ package refsplitR (Fournier et al., 2020) to visualize collaborative networks of these citations (Fig. 4B, C) using the primary institution that an author is affiliated with as a proxy for their country. We subsequently visualized the total number of authors based in each country in the combined citations across all eight journals, scaled by each country's estimated population, using rworldmap (South, 2011). Our results suggest that Latin American researchers are very active participants in Neotropical plant taxonomy today (Fig. 4) and that they are often part of international collaborations, especially between researchers in the United States and western Europe (Fig. 4B, C). Some Latin American countries (e.g., Brazil, Colombia, and Costa Rica) have proportionally more active researchers publishing on Neotropical taxonomy than the United States, while others do not have any representation in our dataset (e.g., Paraguay, Nicaragua, and Surinam). These differences could be explained by lack of established international collaborative collection efforts (as noted above), differences in national funding of scientific infrastructure in the last decade (Ciocca \& Delgado, 2017), or differing academic publishing preferences across countries (Estrada-Mejía \& Forero-Pineda, 2010). We also observed differences in the structure of global networks that reflect the scope and targeted audience of different journals. For example, journals with an explicit global focus (e.g., Phytotaxa) commonly have collaboration networks that span multiple global regions, including both North America and western Europe (Fig. 4B), while regional journals (e.g., Caldasia) have networks centered in the country in which they are based and tend to not extend to more than one region of the Global North (Fig. 4C). Overall, these analyses demonstrate that researchers based in Latin America actively publish on Neotropical plant taxonomy and form key components of international collaborative networks. As decolonization efforts should be collaborative, community-accepted undertakings, any future progress toward this end will benefit from the fact that Latin American voices are already central to Neotropical plant taxonomy, as well as these existing international collaborative networks.

\section{POSITIONALITY STATEMENT}

As white citizens of the United States who are trained as scientists and employed by a major U.S. university, we recognize that we have a platform that is not available to all taxonomists. In both of our careers, we have worked throughout Latin America and in collaboration with a variety of Latin American botanists, and have immensely benefitted from the diverse perspectives that we have encountered in the pursuit of scholarship in Neotropical taxonomy. So while we call for the field to reflect on the colonial history of the field, we also recognize that the present manuscript is an insignificant 
(A)

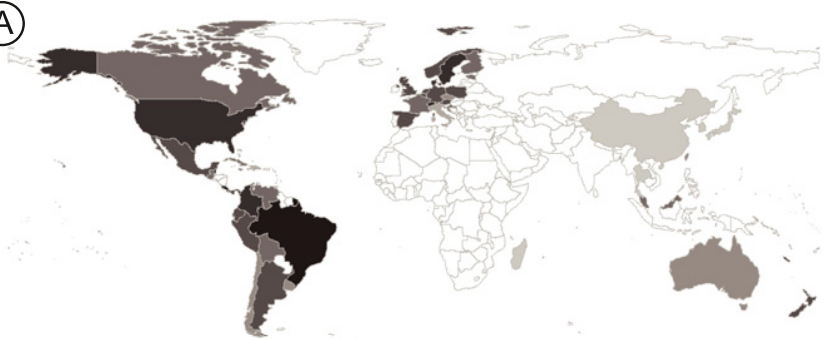

0.0184

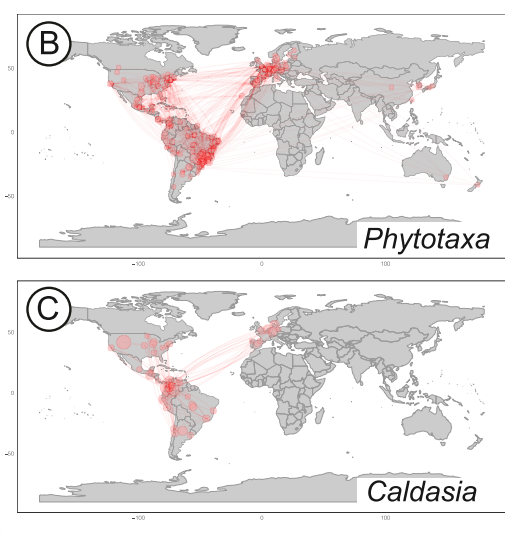

Figure 4. Distribution and networks of authors publishing on Neotropical taxonomy. —A. Global distribution of authors' institutions on Neotropical botany taxonomic publications from eight targeted journals from a Web of Science search, scaled by estimated population of each country. Colors represent number of authors per million on a sliding scale from light gray to black; there were no authors in our dataset from countries in white. - B. Author networks for one journal with an explicitly global reach (Phytotaxa). —C. Author networks for one journal with an explicitly local reach (Caldasia, a Colombian journal).

step toward realizing decolonization. Considerable scholarship, including by social scientists and historians, and input from a diversity of perspectives-especially Latin American and indigenous botanists-are essential to effectively develop and communicate best practices in the decolonialization of Neotropical plant taxonomy.

\section{ConcLusion}

While we are not the first to note the importance of taxonomy for richer biodiversity studies, we emphasize the importance of making this connection clear so that an increased appreciation for detailed understanding of organismal diversity can be achieved. As the line between the fields of taxonomy and evolutionary biology continues to blur, taxonomic experts increasingly use their organismal knowledge to understand important patterns and processes in ecology and evolution. Taxonomists are integrated into expanded collaborative networks that aim to understand the drivers of biodiversity patterns in key model systems, including Bignoniaceae, Protium, and Solanum as discussed above, as well as others featured in the 66th Missouri Botanical Garden symposium such as the Andean lobelioids (Lagomarsino et al., 2017) and Psychotria (Sedio et al., 2013). Furthermore, taxonomic contributions are being published in high-profile, high-impact journals with seemingly increased frequency (Hibbett, 2016; Cardoso et al., 2017; Muñoz-Rodríguez et al., 2019; Rheindt et al., 2020). As we continue to move toward increasingly integrated biodiversity studies, it is critical that taxonomists continue to bring their organismal knowledge to bear on broad questions related to the entire flora of the Neotropics, and that this is done in a way that elevates voices and perspectives from Latin
American countries and indigenous cultures. It is also critical that entire research teams acknowledge the past work of botanists who built the knowledge base from which they are able to generate and test broad hypotheses, as well as the broader historical context in which those taxonomists operated.

\section{Literature Cited}

Acosta-Solis, M. 1969. Protección y conservación de la naturaleza en Sudamérica. Pp. 230-250 in E. J. Fittkau, J. Illies, H. Klinge, G. H. Schwabe \& H. Sioli (editors), Biogeography and Ecology in South America. Springer Netherlands, Dordrecht.

Åkesson, C. M., F. Matthews-Bird, M. Bitting, C.-J. Fennell, W. B. Church, L. C. Peterson, B. G. Valencia, et al. 2020. 2,100 years of human adaptation to climate change in the High Andes. Nat. Ecol. Evol. 4: 66-74.

Alcantara, S. \& L. G. Lohmann. 2010. Evolution of floral morphology and pollination system in Bignonieae (Bignoniaceae). Amer. J. Bot. 97: 782-796.

Alcantara, S. \& L. G. Lohmann. 2011. Contrasting phylogenetic signals and evolutionary rates in floral traits of Neotropical lianas. Biol. J. Linn. Soc. 102: 378-390.

Andersson, L. 1989. An evolutionary scenario for the genus Heliconia. Pp. 173-184 in L. B. Holmnielsen, I. C. Nielsen $\&$ H. Balsev (editors), Tropical Forest: Botanical Dynamics, Speciation and Diversity. Academic Press, London.

Antonelli, A. \& I. Sanmartín. 2011. Why are there so many plant species in the Neotropics? Taxon 60: 403-414.

Antonelli, A., M. Ariza, J. Albert, T. Andermann, J. Azevedo, C. Bacon, S. Faurby, et al. 2017. Conceptual and empirical advances in Neotropical biodiversity research. PeerJ Prepr. 6: e5644.

Bacon, C. D., D. Silvestro, C. Jaramillo, B. T. Smith, P. Chakrabarty \& A. Antonelli. 2015. Biological evidence supports an early and complex emergence of the Isthmus of Panama. Proc. Natl. Acad. Sci. U.S.A. 112: 6110-6115.

Baek, Y. S., S. M. Royer, A. K. Broz, P. A. Covey, G. LópezCasado, R. Nuñez, P. J. Kear, et al. 2016. Interspecific reproductive barriers between sympatric populations of wild 
tomato species (Solanum section Lycopersicon). Amer. J. Bot. 103: 1964-1978.

Baker, K., M. P. Eichhorn \& M. Griffiths. 2019. Decolonizing field ecology. Biotropica 51: 288-292.

Baker, T. R., R. T. Pennington, K. G. Dexter, P. V. A. Fine, H. Fortune-Hopkins, E. N. Honorio, I. Huamantupa-Chuquimaco, et al. 2017. Maximising synergy among tropical plant systematists, ecologists, and evolutionary biologists. Trends Ecol. Evol. 32: 258-267.

Barboza, G. E. 2013. In F. Zuloaga, M. Belgrano \& A. Anton (editors), Flora Vascular de la República Argentina 13: Dicotyledoneae-Solanaceae. Instituto de Botánica Darwinion, San Isidro.

Barlow, J., F. França, T. A. Gardner, C. C. Hicks, G. D. Lennox, E. Berenguer, L. Castello, et al. 2018. The future of hyperdiverse tropical ecosystems. Nature 559: 517-526.

Basset, Y., V. Novotny, S. E. Miller, G. D. Weiblen, O. Missa \& A. J. A. Stewart. 2004. Conservation and biological monitoring of tropical forests: The role of parataxonomists. J. Appl. Ecol. 41: 163-174.

Bebber, D. P., M. A. Carine, J. R. I. Wood, A. H. Wortley, D. J. Harris, G. T. Prance, G. Davidse, et al. 2010. Herbaria are a major frontier for species discovery. Proc. Natl. Acad. Sci. U.S.A. 107: 22169-22171.

Bebber, D. P., J. R. I. Wood, C. Barker \& R. W. Scotland. 2014. Author inflation masks global capacity for species discovery in flowering plants. New Phytol. 201: 700-706.

Bemmels, J. B., S. J. Wright, N. C. Garwood, S. A. Queenborough, R. Valencia \& C. W. Dick. 2018. Filter-dispersal assembly of lowland Neotropical rainforests across the Andes. Ecography 41: 1763-1775.

Berry, P. E., B. K. Holst \& K. Yatskievych. 1995. Flora of the Venezuelan Guayana, Vol. 1. Missouri Botanical Garden Press, St. Louis; Timber Press, Portland.

Brito, I. J. N., S. L. Costa, J. M. P. Cordeiro, L. G. Lohmann \& J. I. M. de Melo. 2018. New records of the Tabebuia alliance (Bignoniaceae) for the state of Paraiba, northeastern Brazil. Rev. Mex. Biodivers. 89: 625-630.

Buyck, B. 1999. Taxonomists are an endangered species in Europe. Nature 401: 321.

Callejas, R. \& A. Idárraga. 2013. Flora de Antioquia: Catálogo de las Plantas Vasculares. Vol. I. Introducción. Editorial D’Vinni, Bogotá.

Campos, L. V., H. ter Steege \& J. Uribe. 2015. The epiphytic bryophyte flora of the Colombian Amazon. Caldasia 37: 47-59.

Cardoso, D., T. Särkinen, S. Alexander, A. M. Amorim, V. Bittrich, M. Celis, D. C. Daly, et al. 2017. Amazon plant diversity revealed by a taxonomically verified species list. Proc. Natl. Acad. Sci. U.S.A. 114: 10695-10700.

Cardoso, P., T. L. Erwin, P. A. V. Borges \& T. R. New. 2011. The seven impediments in invertebrate conservation and how to overcome them. Biol. Conserv. 144: 2647-2655.

Cheng, H., A. Sinha, F. W. Cruz, X. Wang, R. L. Edwards, F. M. d'Horta, C. C. Ribas, et al. 2013. Climate change patterns in Amazonia and biodiversity. Nat. Commun. 4: 1411.

Chomicki, G. \& S. S. Renner. 2015. Watermelon origin solved with molecular phylogenetics including Linnaean material: Another example of museomics. New Phytol. 205: 526-532.

Ciocca, D. R. \& G. Delgado. 2017. The reality of scientific research in Latin America; an insider's perspective. Cell Stress Chaperones 22: 847-852.

Claramunt, S. \& J. Cracraft. 2015. A new time tree reveals Earth history's imprint on the evolution of modern birds. Sci. Adv. 1: el501005.

Clark, L. G. 1990. Chusquea sect. Longiprophyllae (Poaceae: Bambusoideae): A new Andean section and new species. Syst. Bot. 15: 617-634.
Clark, L. G. 2001. Diversification and endemism in Andean woody bamboos (Poaceae: Bambusoideae). J. Amer. Bamboo Soc. 15: 14-19.

Condit, R. 1995. Research in large, long-term tropical forest plots. Trends Ecol. Evol. 10: 18-22.

Costa, S., L. G. Lohmann \& M. T. Buril. 2019. Flora of Pernambuco, Brazil: Tabebuia alliance and tribe Jacarandeae (Bignoniaceae). Biota Neotrop. 19: e20190737. https:// doi.org/10.1590/1676-0611-bn-2019-0737.

Cracraft, J., C. C. Ribas, F. M. d'Horta, J. Bates, R. P. Almeida, P. Baker, J. P. Boubli, et al. 2020. The origin and evolution of Amazonian species diversity. Pp. 225-244 in V. Rull \& A. Carnaval (editors), Neotropical Diversification: Patterns and Processes. Springer, Berlin.

Croat, T. B. 1978. Flora of Barro Colorado Island. Stanford University Press, Stanford.

Cuesta-Camacho, F., A. Ganzenmueller \& F. Baquero. 2006. Predicting distribution of Andean-centered taxa using ecological niche modelling methods. Lyonia 9: 19-33.

Daly, D. C. 1989. Studies in Neotropical Burseraceae. II. Generic limits in New World Protieae and Canarieae. Brittonia 41: 17-27.

Daly, D. C. 1992. New taxa and combinations in Protium Burm. f. Studies in Neotropical Burseraceae VI. Brittonia 44: 280.

Daly, D. C. 2007. A new section of Protium from the Neotropics. Studies in Neotropical Burseraceae XIII. Brittonia 59: 1-24.

Daly, D. C. 2020. New species of Protium sect. Tetragastris from the Andes, the Brazilian Cerrado, and Amazonia. Studies in Neotropical Burseraceae XXVIII. Brittonia. doi:10.1007/s12228-020-09616-x.

Daly, D. C. \& P. V. A. Fine. 2011. A new Amazonian section of Protium (Burseraceae) including both edaphic specialist and generalist taxa. Studies in Neotropical Burseraceae XVI. Syst. Bot. 36: 939-949.

Daly, D. C. \& P. V. A. Fine. 2018. Generic limits re-visited and an updated sectional classification for Protium (tribe Protieae). Studies in Neotropical Burseraceae XXV. Brittonia 70: 418-426.

Daly, D. C., P. V. A. Fine \& M. C. Martínez-Habibe. 2012. Burseraceae: A model for studying the Amazon flora. Rodriguésia 63: 021-030.

Damasco, G., D. C. Daly, A. Vicentini \& P. V. A. Fine. 2019. Reestablishment of Protium cordatum (Burseraceae) based on integrative taxonomy. Taxon 68: 34-46.

Daru, B. H., E. A. Bowman, D. H. Pfister \& A. E. Arnold. 2018a. A novel proof of concept for capturing the diversity of endophytic fungi preserved in herbarium specimens. Philos. Trans., Ser. B 374: 20170395. doi:10.1098/rstb.2017.0395.

Daru, B. H., D. S. Park, R. B. Primack, C. G. Willis, D. S. Barrington, T. J. S. Whitfeld, T. G. Seidler, et al. 2018b. Widespread sampling biases in herbaria revealed from large-scale digitization. New Phytol. 217: 939-955.

Diaz, L. F. H., L. J. Harmon, M. T. C. Sugawara, E. T. Miller \& M. W. Pennell. 2019. Macroevolutionary diversification rates show time dependency. Proc. Natl. Acad. Sci. U.S.A. 116: 7403-7408.

Diazgranados, M., F. Ávila, M. Álvarez, E. Ambrose, D. Baines, A. Barker, D. Bishop, et al. 2019. ColPlantA: Colombian resources for Plants made Accessible. Royal Botanic Gardens, Kew. <http://colplanta.org >.

Dick, C. W. \& M. Heuertz. 2008. The complex biogeographic history of a widespread tropical tree species. Evolution 62: 2760-2774.

Diels, L. 1937. Beiträge zur Kenntnis der Vegetation und Flora von Ecuador. Biblioteca Botanica, Stuttgart.

Dodge, C. W. 1933. The foliose and fruticose lichens of Costa Rica. I. Ann. Missouri Bot. Gard. 20: 373-467. 
Dodsworth, S., L. Pokorny, M. G. Johnson, J. T. Kim, O. Maurin, N. J. Wickett, F. Forest, et al. 2019. Hyb-seq for flowering plant systematics. Trends Pl. Sci. 24: 887-891.

Donoghue, M. J. \& E. J. Edwards. 2019. Model clades are vital for comparative biology, and ascertainment bias is not a problem in practice: A response to Beaulieu and O'Meara (2018). Amer. J. Bot. 106: 327-330.

Druitt, D. G., N. J. Enright \& J. Ogden. 1990. Altitudinal zonation in the mountain forests of Mt Hauhungatahi, North Island, New Zealand. J. Biogeogr. 17: 205-220.

Durand, T. \& H. Pittier. 1891. Primitiae florae costaricensis. Bull. Soc. Roy. Bot. Belgique 30: 7-97.

Durand, T., H. Pittier, J. Müller, F. Renauld \& J. Cardot. 1893. Primitiae florae costaricensis, troisième fascicule. Bull. Soc. Roy. Bot. Belgique 32: 122-201.

Dwyer, J. D. 1964. Panama, plant collection, and the Missouri Botanical Garden. Ann. Missouri Bot. Gard. 51: 109-117.

Echeverría-Londoño, S., T. Särkinen, I. S. Fenton, A. Purvis \& S. Knapp. 2020. Dynamism and context-dependency in diversification of the megadiverse plant genus Solanum (Solanaceae). J. Syst. Evol. doi:10.1111/jse.12638.

Eck, J. L., S. M. Stump, C. S. Delavaux, S. A. Mangan \& L. S. Comita. 2019. Evidence of within-species specialization by soil microbes and the implications for plant community diversity. Proc. Natl. Acad. Sci. U.S.A. 116: 7371-7376.

Eichhorn, M. P., K. Baker \& M. Griffiths. 2020. Steps toward decolonising biogeography. Frontiers Biogeogr. 12: e44795.

Estrada-Mejía, C. \& C. Forero-Pineda. 2010. The quest for visibility of scientific journals in Latin America. Learn. Publ. 23: 237-252.

Exposito-Alonso, M., C. Becker, V. J. Schuenemann, E. Reiter, C. Setzer, R. Slovak, B. Brachi, et al. 2018. The rate and potential relevance of new mutations in a colonizing plant lineage. PLoS Genet. 14: el007155.

Feeley, K. J. \& M. R. Silman. 2011. Keep collecting: Accurate species distribution modelling requires more collections than previously thought. Divers. Distrib. 17: 1132-1140.

Fine, P. V. A. \& L. G. Lohmann. 2018. Importance of dispersal in the assembly of the Neotropical biota. Proc. Natl. Acad. Sci. U.S.A. 115: 5829-5831.

Fine P. V. A., I. Mesones \& P. D. Coley. 2004. Herbivores promote habitat specialization by trees in Amazonian forests. Science 305: 663-665.

Fine, P. V. A., D. C. Daly \& K. M. Cameron. 2005. The contribution of edaphic heterogeneity to the evolution and diversity of Burseraceae trees in the western Amazon. Evolution 59: 1464-1478.

Fine, P. V. A., M. R. Metz, J. Lokvam, I. Mesones, J. M. Ayarza Zuñig, G. P. A. Lamarre, M. Vasquez Pilco, et al. 2013a. Insect herbivores, chemical innovation and the evolution of habitat specialization in Amazonian trees. Ecology 94: 1764-1775.

Fine, P. V. A., F. Zapata, D. C. Daly, I. Mesones, T. M. Misiewicz, H. F. Cooper \& C. E. A. Barbosa. 2013b. The importance of environmental heterogeneity and spatial distance in generating phylogeographic structure in edaphic specialist and generalist tree species of Protium (Burseraceae) across the Amazon Basin. J. Biogeogr. 40: 646-661.

Fine, P. V. A., F. Zapata \& D. C. Daly. 2014. Investigating processes of neotropical rain forest tree diversification by examining the evolution and historical biogeography of the Protieae (Burseraceae). Evolution 68: 1988-2004.

Firetti-Leggieri, F., D. Demarco \& L. G. Lohmann. 2015. A new species of Anemopaegma (Bignonieae, Bignoniaceae) from the Atlantic Forest of Brazil. Phytotaxa 219: 174-182.

Fleming, T. H., R. Breitwisch \& G. H. Whitesides. 1987. Patterns of tropical vertebrate frugivore diversity. Annual Rev. Ecol. Syst. 18: 91-109.
Flora do Brasil. 2020 (under construction). Jardim Botânico do Rio de Janeiro. < http://floradobrasil.jbrj.gov.br/>, accessed on 1 July 2020.

Flores-Palacios, A. \& J. G. García-Franco. 2008. Habitat isolation changes the beta diversity of the vascular epiphyte community in lower montane forest, Veracruz, Mexico. Biodivers. \& Conservation 17: 191-207.

Fonseca, L. H. M. \& L. G. Lohmann. 2019. An updated synopsis of Adenocalymma (Bignonieae, Bignoniaceae). Syst. Bot. 44: 893-912.

Forero, E. 1988. Botanical exploration and phytogeography of Colombia: Past, present and future. Taxon 37: 561-566.

Fortunel, C., C. E. T. Paine, P. V. A. Fine, I. Mesones, J.-Y. Goret, B. Burban, J. Cazal, et al. 2016. There's no place like home: Seedling mortality contributes to the habitat specialisation of tree species across Amazonia. Ecol. Lett. 19: 12561266.

Fournier, A. M., M. E. Boone, F. R. Stevens \& E. M. Bruna. 2020. refsplitr: Author name disambiguation, author georeferencing, and mapping of coauthorship networks with Web of Science data. J. Open Source Softw. 5: 2028.

Frahm, J.-P. \& S. R. Gradstein. 1991. An altitudinal zonation of tropical rain forests using byrophytes. J. Biogeogr. 18: 669-678.

Francisco, J. N. C. \& L. G. Lohmann. 2018. Taxonomic revision of Pachyptera (Bignonieae, Bignoniaceae). Phytotaxa 92: 89-131.

Frazão, A. \& L. G. Lohmann. 2018. A new species of Tanaecium (Bignonieae, Bignoniaceae) from the Brazilian Amazon and its phylogenetic placement. Pl. Syst. Evol. 304: 1245-1253.

Fujita, M. K., A. D. Leaché, F. T. Burbrink, J. A. McGuire \& C. Moritz. 2012. Coalescent-based species delimitation in an integrative taxonomy. Trends Ecol. Evol. 27: 480-488.

Funk, V. A. 2018. Collections-based science in the 21st century. J. Syst. Evol. 56: 175-193.

Funk, V. A. \& N. Morin. 2000. A survey of the herbaria of the southeast United States. Sida Bot. Misc. 18: 35-52.

Funk, V. A. \& K. S. Richardson. 2002. Systematic data in biodiversity studies: Use it or lose it. Syst. Biol. 51: 303316.

Gaston, K. J. \& R. M. May. 1992. Taxonomy of taxonomists. Nature 356: 281-282.

Gentry, A. H. 1982a. Neotropical floristic diversity: Phytogeographical connections between Central and South America, Pleistocene climatic fluctuations, or an accident of the Andean orogeny? Ann. Missouri Bot. Gard. 69: 557-593.

Gentry, A. H. 1982b. Patterns of Neotropical plant species diversity. Pp. 1-84 in M. K. Hecht, B. Wallace \& G. T. Prance (editors), Evolutionary Biology, Vol. 15. Springer, Boston.

Gentry, A. H. 1988. Changes in plant community diversity and floristic composition on environmental and geographical gradients. Ann. Missouri Bot. Gard. 75: 1-34.

Gentry, A. H. 1992. Tropical forest biodiversity: Distributional patterns and their conservational significance. Oikos 63 : 19-28.

Gómez, L. D. \& J. M. Savage. 1983. Searchers on that rich coast: Costa Rican field biology, 1400-1980. Pp. 1-11 in D. H. Janzen (editor), Costa Rican Natural History. University of Chicago Press, Chicago.

Goodwin, Z. A., D. J. Harris, D. Filer, J. R. I. Wood \& R. W. Scotland. 2015. Widespread mistaken identity in tropical plant collections. Curr. Biol. 25: R1066-R1067.

Hamlin, J. A. P. \& L. C. Moyle. 2019. Spatial proximity determines post-speciation introgression in Solanum. bioRxiv. https://doi.org/10.1101/529115. 
Hammel, B. E., M. H. Grayum, C. Herrera \& N. Zamora (editors). 2004. Manual de Plantas de Costa Rica, Vol. I: Introducción. Monogr. Syst. Bot. Missouri Bot. Gard. 97.

Hart, M. L., L. L. Forrest, J. A. Nicholls \& C. A. Kidner. 2016. Retrieval of hundreds of nuclear loci from herbarium specimens. Taxon 65: 1081-1092.

Hart, R., J. Salick, S. Ranjitkar \& J. Xu. 2014. Herbarium specimens show contrasting phenological responses to Himalayan climate. Proc. Natl. Acad. Sci. U.S.A. 111: 10615-10619.

Hawkins, B. A. 2001. Ecology's oldest pattern? Trends Ecol. Evol. 16: 470 .

Heywood, V. H. 1983. The mythology of taxonomy. Trans. Bot. Soc. Edinburgh 44: 79-94.

Heywood, V. 2001. Floristics and monography-An uncertain future? Taxon 50: 361-380.

Hibbett, D. 2016. The invisible dimension of fungal diversity. Science 351: 1150-1151.

Hijmans, R. J., K. A. Garrett, Z. Huamán, D. P. Zhang, M. Schreuder \& M. Bonierbale. 2000. Assessing the geographic representativeness of genebank collections: The case of Bolivian wild potatoes. Conserv. Biol. 14: 1755-1765.

Hinchliff, C. E., S. A. Smith, J. F. Allman, J. G. Burleigh, R. Chaudhary, L. M. Coghill, K. A. Crandall, et al. 2015. Synthesis of phylogeny and taxonomy into a comprehensive tree of life. Proc. Natl. Acad. Sci. U.S.A. 112: 12764-12769.

Hoorn, C., R. van der Ham, F. de la Parra, S. Salamanca, H. ter Steege, H. Banks, W. Star, et al. 2019. Going north and south: The biogeographic history of two Malvaceae in the wake of Neogene Andean uplift and connectivity between the Americas. Rev. Palaeobot. Palynol. 264: 90-109.

Hortal, J., A. Jiménez-Valverde, J. F. Gómez, J. M. Lobo \& A. Baselga. 2008. Historical bias in biodiversity inventories affects the observed environmental niche of the species. Oikos 117: 847-858.

Huber, O. \& J. J. Wurdack. 1984. History of botanical exploration in Territorio Federal Amazonas, Venezuela. Smithsonian Contrib. Bot. 56: 1-83.

Iles, W. J. D., C. Sass, L. Lagomarsino, G. Benson-Martin, H. Driscoll \& C. D. Specht. 2017. The phylogeny of Heliconia (Heliconiaceae) and the evolution of floral presentation. Molec. Phylogen. Evol. 117: 150-167.

Jiménez-Luthmer, O. 1969. La influencia de Humboldt en la cultura de Costa Rica. Rev. Agric. (Piracicaba) 61: 10-11.

Johns, R. J. 1985. Altitudinal zonation of pteridophytes in Papuasia. Proc. Roy. Soc. Edinburgh 86: 381-389.

Jørgensen, P. M. \& S. León-Yánez. 1999. Catalogue of the Vascular Plants of Ecuador. Monogr. Syst. Bot. Missouri Bot. Gard. 75.

Kaehler, M., F. A. Michelangeli \& L. G. Lohmann. 2019. Finetuning the circumscription of Fridericia (Bignonieae, Bignoniaceae). Taxon 68: 751-770.

Kawasaki, M. L. \& Á. J. Pérez. 2012. A new species of Plinia (Myrtaceae) from Ecuador, with demographic notes from a large forest plot. Harvard Pap. Bot. 17: 19-20.

Kessler, M. 2000. Altitudinal zonation of Andean cryptogam communities. J. Biogeogr. 27: 275-282.

Knapp, S. 2002. Assessing patterns of plant endemism in Neotropical uplands. Bot. Rev. 68: 22-37.

Knapp, S. \& M. S. Vorontsova. 2016. A revision of the "African Non-Spiny" Clade of Solanum L. (Solanum sections Afrosolanum Bitter, Benderianum Bitter, Lemurisolanum Bitter, Lyciosolanum Bitter, Macronesiotes Bitter, and Quadrangulare Bitter: Solanaceae). PhytoKeys 66: 1-142.

Knapp, S., L. Bohs, M. Nee \& D. M. Spooner. 2004. Solanaceae-A model for linking genomics with biodiversity. Int. J. Genomics Proteomics 5: 285-291.

Knapp, S., G. E. Barboza, L. Bohs \& T. Särkinen. 2019. A revision of the Morelloid Clade of Solanum L. (Solanaceae) in North and Central America and the Caribbean. PhytoKeys 123: 1-144.

Krömer, T. \& S. R. Gradstein. 2003. Species richness of vascular epiphytes in two primary forests and fallows in the Bolivian Andes. Selbyana 24: 190-195.

Lagomarsino, L. P., F. L. Condamine, A. Antonelli, A. Mulch \& C. C. Davis. 2016. The abiotic and biotic drivers of rapid diversification in Andean bellflowers (Campanulaceae). New Phytol. 210: 1430-1442.

Lagomarsino, L. P., E. J. Forrestel, N. Muchhala \& C. C. Davis. 2017. Repeated evolution of vertebrate pollination syndromes in a recently diverged Andean plant clade. Evolution 71: 1970-1985.

Lendemer, J., B. Thiers, A. K. Monfils, J. Zaspel, E. R. Ellwood, A. Bentley, K. LeVan, et al. 2020. The Extended Specimen Network: A strategy to enhance US biodiversity collections, promote research and education. BioScience 70: 23-30.

León, J. 2002. La exploración botánica de Costa Rica en el siglo XIX. Pp. 161-178 in G. Peraldo Huertas (editor), Ciencia y Técnica en la Costa Rica del Siglo XIX. Editorial Tecnológica de Costa Rica, Cartago.

Lohmann, L. G. 2006. Untangling the phylogeny of neotropical lianas (Bignonieae, Bignoniaceae). Amer. J. Bot. 93: 304318.

Lohmann, L. G. 2010. Bignoniaceae. Pp. 758-772 in R. C. Forzza, J. F. A. Baumgartz, C. E. M. Bicudo, A. A. Carvalho Jr., A. Costa, D. P. Costa, M. Hopkins, et al. (editors), Catálogo de Plantas e Fungos do Brasil. Jardim Botânico do Rio de Janeiro, Rio de Janeiro.

Lohmann, L. G. \& C. Ulloa Ulloa. 2006. Bignoniaceae. iPlants prototype Checklist. New York Botanical Garden, Missouri Botanical Garden, Royal Botanic Gardens, Kew. <http:// www.iplants.org/>.

Lohmann, L. G. \& C. M. Taylor. 2014. A new generic classification of tribe Bignonieae (Bignoniaceae). Ann. Missouri Bot. Gard. 99: 348-489.

Lohmann, L. G., C. D. Bell, M. F. Calió \& R. C. Winkworth. 2013. Pattern and timing of biogeographical history in the Neotropical tribe Bignonieae (Bignoniaceae). Bot. J. Linn. Soc. 171: 154-170.

Lohmann, L. G., F. Firetti \& B. Gomes. 2018. Flora rupestre das cangas da Serra dos Carajás: Bignoniaceae. Rodriguésia 69: 1063-1079.

Loiselle, B. A., P. M. Jørgensen, T. Consiglio, I. Jiménez, J. G. Blake, L. G. Lohmann \& O. M. Montiel. 2007. Predicting species distributions from herbarium collections: Does climate bias in collection sampling influence model outcomes? J. Biogeogr. 35: 105-116.

Lowry, D. B., J. M. Sobel, A. L. Angert, T. Ashman, R. L. Baker, B. K. Blackman, Y. Brandvain, et al. 2019. The case for the continued use of the genus name Mimulus for all monkeyflowers. Taxon 68: 617-623.

Maldonado, C., C. I. Molina, A. Zizka, C. Persson, C. M. Taylor, J. Albán, E. Chilquillo, et al. 2015. Estimating species diversity and distribution in the era of Big Data: To what extent can we trust public databases? Global Ecol. Biogeogr. 24: 973-984.

Martin, M. D., M. T. Olsen, J. A. Samaniego, E. A. Zimmer \& M. T. P. Gilbert. 2016. The population genomic basis of geographic differentiation in North American common ragweed (Ambrosia artemisiifolia L.). Ecol. Evol. 6: 3760-3771.

Martine, C. T., I. E. Jordon-Thaden, A. J. McDonnell, J. T. Cantley, D. S. Hayes, M. D. Roche, E. S. Frawley, et al. 2019. Phylogeny of the Australian Solanum dioicum group using seven nuclear genes, with consideration of Symon's fruit and seed dispersal hypotheses. PLoS ONE 14: e0207564. 
May, R. M. 1992. How many species inhabit the Earth? Sci. Amer. 267: 42-49.

McAllister, C. A., M. R. McKain, M. Li, B. Bookout \& E. A. Kellogg. 2018. Specimen-based analysis of morphology and the environment in ecologically dominant grasses: The power of the herbarium. Philos. Trans., Ser. B 374: 20170403.

McCook, S. 1999. Creole science: Botanical surveys of Costa Rica, 1880-1940. Endeavour 23: 118-120.

Medeiros, M. C. P. \& L. G. Lohmann. 2015. Taxonomic revision of Tynanthus (Bignonieae, Bignoniaceae). Phytotaxa 216: 1-60.

Meineke, E. K. \& T. J. Davies. 2018. Museum specimens provide novel insights into changing plant-herbivore interactions. Philos. Trans., Ser. B 374: 20170393.

Meyer, C., P. Weigelt \& H. Kreft. 2016. Multidimensional biases, gaps and uncertainties in global plant occurrence information. Ecol. Lett. 19: 992-1006.

Miller, J. S., T. M. Barkley, H. H. Iltis, W. H. Lewis, E. Forero, M. Plotkin, O. Phillips, et al. 1996. Alwyn Howard Gentry, 1945-1993: A tribute. Ann. Missouri Bot. Gard. 83: 433460.

Miralles, A., T. Bruy, K. Wolcott, M. D. Scherz, D. Begerow, B. Beszteri, M. Bonkowski, et al. 2020. Repositories for taxonomic data: Where we are and what is missing. Syst. Biol. doi:10.1093/sysbio/syaa026.

Misiewicz, T. M. \& P. V. A. Fine. 2014. Evidence for ecological divergence across a mosaic of soil types in an Amazonian tropical tree: Protium subserratum (Burseraceae). Molec. Ecol. 23: 2543-2558.

Misiewicz, T. M., T. Simmons \& P. V. A. Fine. 2020. The contribution of multiple barriers to reproduction between edaphically divergent lineages in the Amazonian tree Protium subserratum (Burseraceae). Ecol. Evol. 10: 6646-6663.

Montiel, O. M. \& W. D. Stevens. 2019. Botanical studies in Nicaragua: An ongoing journey of 50-plus years. ReVista. 19: $1-4$.

Moreno, S. H. 2004. Naturalists on the Isthmus of Panama: A Hundred Years of Natural History on the Biological Bridge of the Americas. Smithsonian Tropical Research Institute, Panama.

Mori, S. A. 1992. Neotropical floristics and inventory: Who will do the work? Brittonia 44: 372-375.

Muñoz, G. V., N. C. Garwood, M. S. Bass \& H. Navarette, with the Huaorani communities of Guiyero, Timpoca and Dicaro. 2017. The Common Trees of Yasuní: A Guide for Identifying the Common Trees of the Ecuadorian Amazon. Finding Species, Inc., Quito (with Pontifica Universidad Católica del Ecuador, Darwin Initiative, and Natural History $\mathrm{Mu}-$ seum, London).

Muñoz-Rodríguez, P., T. Carruthers, J. R. I. Wood, B. R. M. Williams, K. Weitemier, B. Kronmiller, Z. Goodwin, et al. 2019. A taxonomic monograph of Ipomoea integrated across phylogenetic scales. Nat. Plants 5: 1136-1144.

Murphy, B., M. de la Estrella, R. Schley, F. Forest \& B. Klitgård. 2018. On the monophyly of Macrolobium Schreb., an ecologically diverse Neotropical tree genus (Fabaceae-Detarioideae). Int. J. Plant Sci. 179: 75-86.

Nazareno, A. G., C. W. Dick \& L. G. Lohmann. 2017. Wide but not impermeable: Testing the riverine barrier hypothesis for an Amazonian plant species. Molec. Ecol. 26: 3636-3648.

Nesom, G. L., N. S. Fraga, W. R. Barker, P. M. Beardsley, D. C. Tank, B. G. Baldwin \& R. G. Olmstead. 2019. Response to "The case for the continued use of the genus name Mimulus for all monkeyflowers." Taxon 68: 624-627.

Nevado, B., E. L. Y. Wong, O. G. Osborne \& D. A. Filatov. 2019. Adaptive evolution is common in rapid evolutionary radiations. Curr. Biol. 29: 3081-3086.e5.
Nieder, J., S. Engwald, M. Klawun \& W. Barthlott. 2000. Spatial distribution of vascular epiphytes (including hemiepiphytes) in a lowland Amazonian rain forest (Surumoni Crane Plot) of southern Venezuela. Biotropica 32: 385-396.

Nogueira, A., P. J. Rey \& L. G. Lohmann. 2012. Evolution of extrafloral nectaries: Adaptive process and selective regime changes from forest to savanna. J. Evol. Biol. 25: 23252340 .

Nogueira, A., P. J. Rey, J. M. Alcántara, R. M. Feitosa \& L. G. Lohmann. 2015. Geographic mosaic of plant evolution: Extrafloral nectary variation mediated by ant and herbivore assemblages. PLoS ONE 10: e0123806.

Norris, W. R., D. Q. Lewis, M. P. Widrlechner, J. D. Thompson $\&$ R. O. Pope. 2001. Lessons from an inventory of the Ames, Iowa, flora (1859-2000). J. Iowa Acad. Sci. 108: 34-63.

Obermüller, F. A., M. Silveira, C. I. Salimon \& D. C. Daly. 2012. Epiphytic (including hemiepiphytes) diversity in three timber species in the southwestern Amazon, Brazil. Biodivers. \& Conservation 21: 565-575.

Ohsawa, M., P. H. J. Nainggolan \& N. Tanaka. 1985. Altitudinal zonation of forest vegetation on Mount Kerinci, Sumatra: With comparisons to zonation in the temperate region of east Asia. J. Trop. Ecol. 1: 193-216.

Oleas, N. H., K. J. Feeley, J. Fajardo, A. W. Meerow, J. Gebelein \& J. Francisco-Ortega. 2019. Muddy boots beget wisdom: Implications for rare or endangered plant species distribution models. Diversity 11: 10. https://doi.org/10.3390/ d11010010.

One Thousand Plant Transcriptomes Initiative. 2019. One thousand plant transcriptomes and the phylogenomics of green plants. Nature 574: 679-685.

Pace, M., L. G. Lohmann \& W. Angyalossy. 2011. Evolution of disparity between the regular and variant phloem in Bignonieae (Bignoniaceae). Amer. J. Bot. 98: 602-618.

Pace, M. R., S. Alcantara, L. G. Lohmann \& V. Angyalossy. 2015. Secondary phloem diversity and evolution in Bignonieae (Bignoniaceae). Ann. Bot. 116: 333-358.

Paknia, O., H. Rajaei Sh \& A. Koch. 2015. Lack of wellmaintained natural history collections and taxonomists in megadiverse developing countries hampers global biodiversity exploration. Organisms Diversity Evol. 15: 619-629.

Park, D. S., I. Breckheimer, A. C. Williams, E. Law, A. M. Ellison \& C. C. Davis. 2018. Herbarium specimens reveal substantial and unexpected variation in phenological sensitivity across the eastern United States. Philos. Trans., Ser. B 374: 20170394.

Pease, J. B., D. C. Haak, M. W. Hahn \& L. C. Moyle. 2016. Phylogenomics reveals three sources of adaptive variation during a rapid radiation. PLoS Biol. 14: el002379.

Pendry, C. A. \& J. Proctor. 1996. The causes of altitudinal zonation of rain forests on Bukit Belalong, Brunei. J. Ecol. 84: 407-418.

Pennington, R. T. \& C. W. Dick. 2010. Diversification of the Amazonian flora and its relation to key geological and environmental events: A molecular perspective. Pp. 373385 in C. Hoorn \& F. P. Wesselingh (editors), Amazonia, Landscape and Species Evolution. Blackwell, Oxford, United Kingdom.

Phillips, O. \& J. S. Miller. 2002. Global Patterns of Plant Diversity: Alwyn H. Gentry's Forest Transect Data Set. Monogr. Syst. Bot. Missouri Bot. Gard. 89.

Pinto, P. \& P. M. Ruiz. 1984. Flora de Colombia. Universidad Nacional de Colombia, Bogotá.

Pinto, R. B., B. M. Torke \& V. Freitas de Mansano. 2012. Updates to the taxonomy of Swartzia (Leguminosae) in extraAmazonian Brazil, with descriptions of five new species and a regional key to the genus. Brittonia 64: 119-138. 
Pirie, M. D., L. W. Chatrou, J. B. Mols, R. H. J. Erkens \& J. Oosterhof. 2006. "Andean-centred" genera in the shortbranch clade of Annonaceae: Testing biogeographical hypotheses using phylogeny reconstruction and molecular dating. J. Biogeogr. 33: 31-46.

Pittier, H. 1908. Ensayo sobre las Plantas Usuales de Costa Rica. H. L. \& J. B. McQueen, Inc., Washington, D.C.

Polakowsky, H. 1879. Die Pflanzenwelt von Costa-Rica. Dresden.

Por, F. D. 2007. A "taxonomic affidavit": Why it is needed? Integr. Zool. 2: 57-59.

Prata, E. M. B., C. Sass, D. P. Rodrigues, F. M. C. B. Domingos, C. D. Specht, G. Damasco, C. C. Ribas, et al. 2018. Toward integrative taxonomy in Neotropical botany: Disentangling the Pagamea guianensis species complex (Rubiaceae). Bot. J. Linn. Soc. 188: 213-231.

Pupim, F. N., A. O. Sawakuchi, R. P. Almeida, C. C. Ribas, A. K. Kern, G. A. Hartmann, C. M. Chiessi, et al. 2019. Chronology of terra firme formation in Amazonian lowlands reveals a dynamic Quaternary landscape. Quatern. Sci. Rev. 210: 154-163.

Quijano-Abril, M. A., R. Callejas-Posada \& D. R. MirandaEsquivel. 2006. Distributional patterns and endemism areas of the Neotropical species of Piper (Piperaceae). J. Biogeogr. 33: 1266-1278.

Rabeler, R. K., H. T. Svoboda, B. Thiers, L. A. Prather, J. A. Macklin, L. P. Lagomarsino, L. C. Majure, et al. 2019. Herbarium practices and ethics, III. Syst. Bot. 44: 7-13.

Reginato, M. 2016. monographaR: An R package to facilitate the production of plant taxonomic monographs. Brittonia 68: 212-216.

Renner, S. S. 1993. A history of botanical exploration in Amazonian Ecuador, 1739-1988. Smithsonian Contr. Bot. 82: 1-39.

Rheindt, F. E., D. M. Prawiradilaga, H. Ashari, Suparno, C. Y. Gwee, G. W. X. Lee, M. Y. Wu, et al. 2020. A lost world in Wallacea: Description of a montane archipelagic avifauna. Science 367: 167-170.

Ribas, C. C., A. Aleixo, A. C. R. Nogueira, C. Y. Miyaki \& J. Cracraft. 2012. A palaeobiogeographic model for biotic diversification within Amazonia over the past three million years. Proc. Biol. Sci. 279: 681-689.

Ricklefs, R. E. \& F. He. 2016. Region effects influence local tree species diversity. Proc. Natl. Acad. Sci. U.S.A. 113: 674-679.

Salazar, D., J. Lokvam, I. Mesones, M. Vásquez Pilco, J. M. Ayarza Zuñiga, P. de Valpine \& P. V. A. Fine. 2018. Origin and maintenance of chemical diversity in a species-rich tropical tree lineage. Nat. Ecol. Evol. 2: 983-990.

Sangster, G. \& J. A. Luksenburg. 2015. Declining rates of species described per taxonomist: Slowdown of progress or a side-effect of improved quality in taxonomy? Syst. Biol. 64: 144-151.

Särkinen, T. \& S. Knapp. 2016. Two new non-spiny Solanum (Solanaceae) from the Gran Chaco Americano and a key for the herbaceous glandular-pubescent solanums from the region. PhytoKeys 74: 19-33.

Särkinen, T., L. Bohs, R. G. Olmstead \& S. Knapp. 2013a. A phylogenetic framework for evolutionary study of the nightshades (Solanaceae): A dated 1000-tip tree. BMC Evol. Biol. 13: 214 .

Särkinen, T., P. Gonzáles \& S. Knapp. 2013b. Distribution models and species discovery: The story of a new Solanum species from the Peruvian Andes. PhytoKeys 31: 1-20.

Särkinen, T., G. E. Barboza \& S. Knapp. 2015a. True black nightshades: Phylogeny and delimitation of the Morelloid clade of Solanum. Taxon 64: 945-958.
Särkinen, T., S. Knapp \& M. Nee. 2015b. Two new non-spiny Solanum species from the Bolivian Andes (Morelloid Clade). PhytoKeys 47: 97-109.

Sauquet, H. \& S. W. Graham. 2016. Planning the future of plant systematics: Report on a special colloquium at the Royal Netherlands Academy of Arts and Sciences. Amer. J. Bot. 103: 2022-2027.

Schindel, D. E. \& J. A. Cook. 2018. The next generation of natural history collections. PLoS Biol. 16: e2006125.

Schlick-Steiner, B. C., F. M. Steiner, B. Seifert, C. Stauffer, E. Christian \& R. H. Crozier. 2010. Integrative taxonomy: A multisource approach to exploring biodiversity. Annual Rev. Entomol. 55: 421-438.

Sedio, B. E. 2017. Recent breakthroughs in metabolomics promise to reveal the cryptic chemical traits that mediate plant community composition, character evolution and lineage diversification. New Phytol. 214: 952-958.

Sedio, B. E., J. R. Paul, C. M. Taylor \& C. W. Dick. 2013. Finescale niche structure of Neotropical forests reflects a legacy of the Great American Biotic Interchange. Nat. Commun. 4: 2317.

Shorthouse, D. P. \& R. Page. 2019. Quantifying institutional reach through the human network in natural history collections. Biodivers. Inform. Sci. Standards 3: e35243.

Sklenáŕ, P. 2006. Searching for altitudinal zonation: Species distribution and vegetation composition in the superpáramo of Volcán Iliniza, Ecuador. Pl. Ecol. 184: 337-350.

Snowden, J. D. 1933. A study in altitudinal zonation in south Kigezi and on Mounts Muhavura and Mgahinga, Uganda. J. Ecol. 21: 7-27.

Sousa-Baena, M. S., N. R. Sinha \& L. G. Lohmann. 2014. Evolution and development of tendrils in Bignonieae (Bignoniaceae, Lamiales). Ann. Missouri Bot. Gard. 99: 323-347.

South, A. 2011. rworldmap: A new R package for mapping global data. R J. 3: 35-43.

Spooner, D. M., H. Ruess, C. I. Arbizu, F. Rodríguez \& C. Solís-Lemus. 2018. Greatly reduced phylogenetic structure in the cultivated potato clade (Solanum section Petota pro parte). Amer. J. Bot. 105: 60-70.

Standley, P. C. 1937. Flora of Costa Rica. Part I. Flora de Costa Rica. Parte I. Field Mus. Nat. Hist., Bot. Ser. 18: 401-408.

Stern, S., L. Bohs, L. Giacomin, J. Stehman \& S. Knapp. 2013. A revision of Solanum section Gonatotrichum. Syst. Bot. 38: 471-496.

Stevens, W. D., C. Ulloa Ulloa, A. Pool \& O. M. Montiel. 2001. Flora de Nicaragua. Monogr. Syst. Bot. Missouri Bot. Gard. 85.

Strasser, B. J. 2019. Collecting Experiments: Making Big Data Biology. University of Chicago Press, Chicago.

Tancoigne, E. \& A. Dubois. 2013. Taxonomy: No decline, but inertia. Cladistics 29: 567-570.

Taylor, D. W. 1991. Paleobiogeographic relationships of Andean angiosperms of Cretaceous to Pliocene age. Palaeogeogr. Palaeoclimatol. Palaeoecol. 88: 69-84.

Thode, V. A., I. Sanmartín \& L. G. Lohmann. 2019. Contrasting patterns of diversification between Amazonian and Atlantic forest clades of Neotropical lianas (Amphilophium, Bignonieae) inferred from plastid genomic data. Molec. Phylogen. Evol. 133: 92-106.

Tonduz, A. 1895. Exploraciones Botánicas en Talamanca: Informe Preliminar. Tipografia Nacional, San José, Costa Rica.

Troudet, J., P. Grandcolas, A. Blin, R. Vignes-Lebbe \& F. Legendre. 2017. Taxonomic bias in biodiversity data and societal preferences. Sci. Rep. 7: 9132.

Turrill, W. B. 1957. The subjective element in plant taxonomy. Bull. Jard. Bot. État. Bruxelles 27: 1-8. 
Uhlig, S. K. \& K. Uhlig. 1991. Studies on the altitudinal zonation of forests and alpine plants in the Central Bale Mountains, Ethiopia. Mt. Res. Dev. 11: 153-156.

Umaña, M. N. \& N. G. Swenson. 2019. Intraspecific variation in traits and tree growth along an elevational gradient in a subtropical forest. Oecologia 191: 153-164.

van der Werff, H. \& S. Nishida. 2010. Yasunia (Lauraceae), a new genus with two species from Ecuador and Peru. Novon 20: 493-502.

Vellend, M., C. D. Brown, H. M. Kharouba, J. L. McCune \& I. H. Myers-Smith. 2013. Historical ecology: Using unconventional data sources to test for effects of global environmental change. Amer. J. Bot. 100: 1294-1305.

Villamil-Montero, D. A. \& L. C. Ming. 2016. Las exploraciones botánicas en Colombia: Una revisión al legado botánico literario con análisis de las colecciones de Lamiaceae como estudio de caso. Bol. Latinoamer. Caribe Pl. Med. Aromát. 15: 128-135.

Vleminckx, J., D. Salazar, C. Fortunel, I. Mesones, N. Dávila, J. Lokvam, K. Beckley, et al. 2018. Divergent secondary metabolites and habitat filtering both contribute to tree species coexistence in the Peruvian Amazon. Frontiers Pl. Sci. 9: 836.

von Humboldt, A. \& A. Bonpland. 1807. Ideen zu einer Geographie der Pflanzen nebst einem Naturgemälde der Tropenländer. Cotta, Tübingen.

Wägele, H., A. Klussmann-Kolb, M. Kuhlmann, G. Haszprunar, D. Lindberg, A. Koch \& J. W. Wägele. 2011. The taxonomist-An endangered race. A practical proposal for its survival. Frontiers Zool. 8: 25.

Wang, X., R. L. Edwards, A. S. Auler, H. Cheng, X. Kong, Y. Wang, F. W. Cruz, et al. 2017. Hydroclimate changes across the Amazon lowlands over the past 45,000 years. Nature 541: 204-209.
Weeks, B. C., S. Claramunt \& J. Cracraft. 2016. Integrating systematics and biogeography to disentangle the roles of history and ecology in biotic assembly. J. Biogeogr. 43: 1546-1559.

Weese, T. L. \& L. Bohs. 2007. A three-gene phylogeny of the genus Solanum (Solanaceae). Syst. Bot. 32: 445-463.

Werner, Y. L. 2006. The case of impact factor versus taxonomy: A proposal. J. Nat. Hist. 40: 1285-1286.

Whanga, H., W. Papa, P. Wehi \& T. Roa. 2013. The use of the Māori language in species nomenclature. J. Mar. Island Cultures. 2: 78-84.

Wheeler, Q. 2020. A taxonomic renaissance in three acts. Megataxa 1: 4-8.

Wiggins, I. L., D. M. Porter \& E. F. Anderson. 1971. Flora of the Galápagos Islands. Stanford University Press, Stanford.

Wolf, J. H. D. \& F.-S. Alejandro. 2003. Patterns in species richness and distribution of vascular epiphytes in Chiapas, Mexico. J. Biogeogr. 30: 1689-1707.

Woodson, R. E. \& R. W. Schery. 1980. Flora of Panama. Ann. Missouri Bot. Gard. 67: ii-xxxiii.

Xi, Z., B. R. Ruhfel, H. Schaefer, A. M. Amorim, M. Sugumaran, K. J. Wurdack, P. K. Endress, et al. 2012. Phylogenomics and a posteriori data partitioning resolve the Cretaceous angiosperm radiation Malpighiales. Proc. Natl. Acad. Sci. U.S.A. 109: 17519-17524.

Yang, Z. 2015. The BPP program for species tree estimation and species delimitation. Curr. Zool. 61: 854-865.

Zapata, F. 2018. Dynamic monographs: Gateways to herbarium data for the future. <https:/hub.ki/groups/modernizingmonography $>$.

Zapata, F. \& I. Jiménez. 2012. Species delimitation: Inferring gaps in morphology across geography. Syst. Biol. 61: 179-194.

Zapata, F. \& P. V. A. Fine. 2013. Diversification of the monoterpene synthase gene family (TPSb) in Protium, a highly diverse genus of tropical trees. Molec. Phylogen. Evol. 68: 432-442. 